\title{
En mann med smerter etter kneoperasjon
}

\author{
En tidligere frisk mann i 30-årene utviklet intense knesmerter etter \\ elektiv artroskopisk knekirurgi. Grundige kliniske overveielser og labo- \\ ratoriediagnostiske funn var viktig for å stille riktig diagnose og dermed \\ få gitt adekvat behandling.
}

\author{
Håkon Reikvam \\ Medisinsk avdeling \\ Haukeland universitetssykehus \\ og \\ Institutt for indremedisin \\ Medisinsk-odontologisk fakultet \\ Universitetet i Bergen \\ Øystein Power \\ Medisinsk avdeling \\ Pål Høvding \\ Ortopedisk avdeling \\ Paul Christoffer Lindemann \\ Mikrobiologisk avdeling \\ Haukeland universitetssykehus \\ Haakon Sjursen \\ haakon.sjursen@helse-bergen.no \\ Medisinsk avdeling \\ Haukeland universitetssykehus \\ og \\ Institutt for indremedisin \\ Medisinsk-odontologisk fakultet \\ Universitetet i Bergen
}

Pasienten var en mann i 30-årene med kjent psoriasis uten kjent leddaffeksjon. Han hadde hatt smerter i høyre kne over lengre tid. Det ble derfor gjort en partiell artroskopisk synovektomi. Selve inngrepet var komplikasjonsfritt. Femte postoperative dag utviklet han smerter og hevelse i høyre kne. Han hadde liten effekt av paracetamol/kodeintabletter. Han ble undersøkt ved ortopedisk poliklinikk sjette postoperative dag. Da fant man hevelse og nedsatt bevegelighet $i$ kneet samt upåfallende innstikksår. Han var afebril og $i$ god allmenntilstand. Blodprøver viste hemoglobin ( $\mathrm{Hb})$ 13,6 $\mathrm{g} / \mathrm{dl}(13,4-17,0)$, leukocytter $12,9 \cdot 10^{9} / \mathrm{l}(3,5-11,0)$, trombocytter $297 \cdot 10^{9} / \mathrm{l}(145-348)$ og C-reaktivt protein (CRP) $197 \mathrm{mg} / \mathrm{l}$ (< 5). Man mistenkte ikke infeksjon, og det ble gjort en artrocentese av høyre kne, der man tappet $55 \mathrm{ml}$ gammelt blod.

Hos pasienter som har gjennomgått ortopedisk kirurgi er smerter i relasjon til opererte ledd eller knokkel vanlig postoperativt, også etter artroskopier (1). Smertene pleier å avta i det postoperative forløpet, men kan være protraherte uten at organpatologi foreligger (1). Reaktive forandringer i ledd etter artroskopi er vanlig og skyldes mobilisering av inflammasjonsmediatorer og -celler postoperativt. Reaktive systemendringer som affiserer blodbildet, ofte med en reaktiv leukocytose og trombocytose er vanlig, det samme er CRP-stigning (2). Differensialdiagnostisk er postoperativ infeksjon vanskelig, men viktig, å utelukke (1-4). Generelle symptomer som feber og redusert allmenntilstand taler for dette. Det samme gjør lokale symptomer som tilkommet erytem, varmeøkning, økende smerter og hevelse over affiserte ledd eller pussekresjon (3). Hos denne pasienten ble det initialt ikke mistenkt infeksjon, og videre konservativ behandling ble forsøkt.

Sjuende postoperative dag tok pasienten igjen kontakt og informerte om at kneet var blitt mer hovent. Han fikk da beskjed om å ta kontakt ved økende symptomer. Åttende postoperative dag var symptomene ytterligere forverret, og det ble besluttet at han skulle legges inn i sykehus. Ved innleggelse var han afebril og respiratorisk og sirkulatorisk stabil. Det var normale funn ved undersøkelse av hjerte, lunger og abdomen. Ved undersøkelse av kneet var det hevelse og temperaturøkning rundt hele kneleddet, hevelse $i$ underekstremiteten fra over kneleddet og til ankelnivå samt smerter ved palpasjon, mest uttalt over patella. Blodpøver viste $\mathrm{Hb} 12,0 \mathrm{~g} / \mathrm{dl}$, leukocytter $11,7 \cdot 10^{9} / \mathrm{l}$, trombocytter $391 \cdot 10^{9} / \mathrm{l}$ og CRP $344 \mathrm{mg} / \mathrm{l}$. Det ble mistenkt enten pågående blødning eller infeksjon i leddet. Det ble derfor gjort en ny artroskopi. Ved innføring av skopet lokaliserte man tyktflytende mørkt blod som ble tappet, og det ble tatt prøver til mikrobiologisk dyrking og mikroskopering. Det var tegn til synovitt, men patella var blank og speilende. Peroperativt vurdert var det ikke sterk mistanke om infeksjon, men mer sannsynlig pågående blødning. Ettersom infeksjon ikke sikkert kunne utelukkes, valgte man likevel å starte med kloksacillin og gentamicin på empirisk grunnlag. Tredje dag etter at det var gjort ny artroskopi, var pasienten i klinisk bedring. Han var afebril og hadde fredelige forhold over kneleddet. Svar fra mikrobiologiske prøver forelå ikke. CRP var synkende til $305 \mathrm{mg} / \mathrm{l}$. Antibiotika ble seponert, da man tolket smertene og CRP-stigningen som postoperativt reaktivt betinget, mulig grunnet blødning i leddet.

Både peroperativ og postoperativ vurdering av infeksjon i ledd kan være vanskelig (3). Blødning kan ytterligere vanskeliggjøre prosessen og bidra til å komplisere vurderingen (3). Mikrobiologisk prøvetaking er viktig, men det vil ta noen dager før prøvesvar foreligger og behandling på klinisk mistanke er vanlig. Dersom infeksjon ikke mistenkes, er det naturlig å seponere antibiotika, slik det ble gjort i dette tilfellet.

Én dag etter seponering av antibiotika utviklet pasienten for første gang i sykdomsforløpet feber. Det var i tillegg økende smerter i kneleddet og CRP steg til $353 \mathrm{mg} / \mathrm{l}$. Det ble på ny startet med antibiotika, denne gang med vankomycin for å gi bedre dekning mot stafylokokkinfeksjon. Smertene var intense og krevde opioidanalgetika. Det ble ikke funnet indikasjon for ny artroskopi. Seks dager etter reskopering kom det preliminært svar fra mikrobiologisk avdeling om oppvekst av hvite stafylokokker i leddvæske. For ytterligere å bedre dekningen mot hvite stafylokokker la man til gentamicin. CRP var da falt til $244 \mathrm{mg} / \mathrm{l}$, men han hadde fortsatt betydelige smerter $i$ kneleddet og var vedvarende subfebril.

Mens hvite stafylokokker tidligere ble ansett kun å representere forurensning fra hudens normalflora, er man de siste årene blitt klar over at det også finnes virulente stammer av hvite stafylokokker som kan gi infeksjoner $(5,6)$. Spesielt synes hvite stafylokokker ofte å komme ved proteseinfeksjoner, da i form av ortopediske proteseinfeksjoner, proteseendokarditt eller andre transplantatinfeksjoner (5). Biofilmproduksjon synes å være den viktigste virulensfaktoren (6). Infeksjoner med hvite stafylokokker uten fremmedlegemer er heller ikke uvanlige, men sammenliknet med gule stafylokokker gir hvite stafylokokker ofte et mer lavgradig forløp med mindre stigning i kliniske og biokjemiske markører (5).

Antibiotikabehandling ble kontinuert, og CRP var lett fallende. To dager etter initialt svar om hvite stafylokokker i leddvæske kom 
endelig mikrobiologisk svar. Det viste oppvekst av to typer hvite stafylokokker i leddvæsken: Staphylococcus lugdunensis og Staphylococcus epidermidis. Identifikasjon av bakteriene ble initialt gjort med systemet Vitek II (bioMérieux). Funn og identifikasjon ble senere verifisert med polymerasekjedereaksjonstest rettet mot variable regioner av 16S rRNA-genet, direkte fra prøvematerialet. Begge mikrobene hadde samme resistensmønster og var resistente for penicillin $G$, men sensitive for følgende antibiotika: oksacillin (kloksacillin), gentamicin, klindamycin, vankomycin, trimetoprim-sulfa, fusidin og linezolid. Antibiotikaregimet ble på nytt vurdert og man valgte å skifte over til kloksacillin $2 \mathrm{~g} \times 6$, gentamicin $5 \mathrm{mg} / \mathrm{kg} \times 1$ og linezolid $600 \mathrm{mg} \times 2$. De to første ble gitt intravenøst, og linezolid ble gitt peroralt. $\mathrm{Pa}$ sienten hadde vedvarende intense smerter $i$ kneleddet, til tross for antibiotikabehandling. Det ble besluttet å gjøre en ny atroskopi av leddet. Det ble på ny tappet ut blodig leddvæske. Det var ikke sikkert puss, men mulig mer blakket leddvæske enn normalt. For øvrig var det upåfallende forhold $i$ selve leddet. Antibiotikabehandling ble kontinuert. Behandlingen hadde god effekt klinisk, med mindre hevelse, og biokjemisk med fallende CRP. Forløpet var fortsatt noe protrahert og han trengte ytterligere 14 dagers behandling som dagpasient med kloksacillin intravenøst og linezolid peroralt. Han kunne utskrives fra avdelingen i god allmenntilstand og med betydelig tilbakegang av symptomene fra kneleddet. Ved utskrivning var CRP falt til $7 \mathrm{mg} / \mathrm{l}$.

\section{Diskusjon}

Postoperativ infeksjon etter artroskopi er en sjelden, men potensielt alvorlig komplikasjon til atroskopi (3). Insidensen er trolig $<1 \%$ (3), og stafylokokker synes å være den dominerende patogene mikroben $(3,4)$. Fenotypiske karakteristika for ulike stafylokokkstammer er ofte klassifisert ut fra deres evne til å produsere koagulase $(5,6)$. Gule stafylokokker (S aureus) er særmerket med at de ofte har en betydelig koagulaseproduksjon, en egenskap de fleste hvite stafylokokker mangler (6). Viktige unntak finnes likevel; vi har både koagulasenegative gule stafylokokker og koagulasepositive hvite stafylokokker.

Hos denne pasienten ble en av mikrobene identifisert som S lugdunensis. Denne mikroben ble første gang beskrevet i 1988 i Lyon i Frankrike og fikk sitt navn etter det latinske navnet på Lyon, Lugdunum (7). Mikroben er en grampositiv, katalasepositiv, men koagulasenegativ stafylokokk (8). Den er ikke motil, den er fakultativ anaerob og kan hemolysere ved dyrking på blodagar (8) (fig 1). Selv om den ikke sekrerer koagulase, kan noen isolater produsere membranbundet koagulase (clumping factor/protein A), noe som kan gi et svakt positivt utslag på stafylokokkagglutinasjonstest (8). Dette gir S lugdunensis egenskaper som gjør den betydelig mer virulent enn andre hvite stafylo-

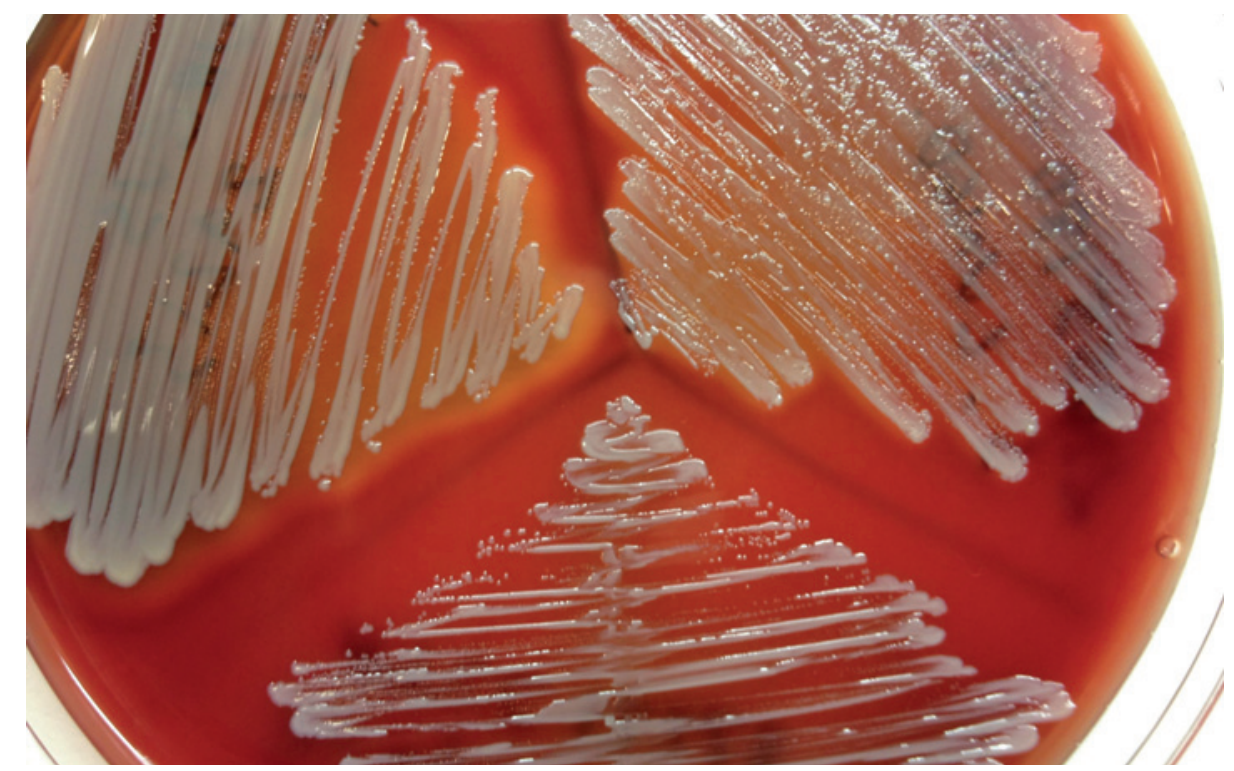

Figur 1 Tre ulike stafylokokkstammer sådd ut på samme agar: S aureus (oppe til venstre), S lugdunensis loppe til høyre) og S epidermidis (nede). Legg merke til den ulike graden av hemolyse som er betydelig for S aureus, moderat for S lugdunensis og ikke til stede for S epidermidis. Illustrasjonsfoto Paul Christoffer Lindemann, Mikrobiologisk avdeling. Haukeland universitetssykehus kokker, og dermed egenskaper som minner om $\mathrm{S}$ aureus $(5,9)$.

Tabell 1 viser karakteristika for S aureus, $\mathrm{S}$ epidermidis og S lugdunensis samt de viktigste testene som brukes i mikrobiologiske laboratorier for å subklassifisere stafylokokker (10). 16S rDNA-sekvensering er også et nyttig diagnostisk hjelpemiddel for å typebestemme mikrober. Ulike kliniske manifestasjoner som osteomyelitt, septisk artritt, endokarditt og toksisk sjokk-syndrom er beskrevet ved S lugdunensis-infeksjoner $(8,9)$. Artritt forårsaket av S lugdunensis i ikke-kunstige ledd er beskrevet tidligere (11, 12), men er sjelden. Selv om S lugdunensis er mer virulent enn andre koagulasenegative stafylokokker, er den - i motsetning til disse - vanligvis sensitiv for de fleste antimikrobielle midler $(9,13)$. Betalaktamaseproduksjon er beskrevet i $15-20 \%$ av isolater (13). $\mathrm{S}$ lugdunensis-stammen som ble identifisert hos den aktuelle pasienten, var resistent for penicillin $\mathrm{G}$, men sensitiv for alle de øvrige antimikrobielle midlene som ble evaluert. Vi valgte likevel å behandle ham med en kombinasjon av flere midler. Grunnen til at vi valgte å legge til linezolid, selv om kloksacillin og gentamicin ut fra resistensmønster og biotilgjengelighet skulle virke adekvat, var manglende respons på denne behandlingen. I tillegg har S lugdunensis-infeksjoner ofte et relativt aggressivt og protrahert forløp, og vi ønsket derfor å forbedre dekningen ytterligere. Utvikling av resistens under pågående behandling er også beskrevet for S lugdunensis (12). Adekvat mikrobiologisk prøvetaking er viktig for å stille rett diagnose og må alltid gjøres før antibiotikabehandling startes. S lugdunensis-infeksjoner er sannsynlig underrapportert, fordi mange laboratorier rutinemessig ikke nærlokokker $(9,11)$. Ved alvorlige infeksjoner med koagulasenegative stafylokokker bør subklassifisering gjøres, og i motsetning til andre koagulasenegative stafylokokker som f.eks. S epidermidis, bør S lugdunensis alltid anses som en reell patogen mikrobe (9).

Pasienten har samtykket til at artikkelen blir publisert.

$>>$ mere identifiserer koagulasenegative stafy-

Tabell 1 Mikrobiologiske kjennetegn og mikrobiologiske tester for subklassifisering av ulike stafylokokkstammer (10)

\begin{tabular}{|c|c|c|c|c|c|}
\hline Mikrobe & $\begin{array}{c}\text { Beta- } \\
\text { hemolyse } \\
{[\%]}\end{array}$ & Katalase & Koagulase & $\begin{array}{l}\text { S aureus-aggluti- } \\
\text { nasjon (clumping } \\
\text { factor/protein A) }\end{array}$ & $\begin{array}{l}\text { Termostabil } \\
\text { nuklease } \\
\text { (nuc-gen) }\end{array}$ \\
\hline $\begin{array}{l}\text { Staphylococcus } \\
\text { aureus }\end{array}$ & $>90$ & + & + & + & + \\
\hline $\begin{array}{l}\text { Staphylococcus } \\
\text { epidermidis }\end{array}$ & $11-89$ & + & - & - & - \\
\hline $\begin{array}{l}\text { Staphylococcus } \\
\text { lugdunensis }\end{array}$ & $>90$ & + & - & $(+)$ & - \\
\hline
\end{tabular}




\section{Håkon Reikvam (f. 1978)}

er ph.d. og lege i spesialisering i indremedisin, Haukeland universitetssykehus, med primær forskningsinteresse innen blodsykdommer og transfusjonsmedisin.

Forfatter har fylt ut ICMJE-skjemaet og oppgir ingen interessekonflikter.

\section{Øystein Power (f. 1976)}

er lege i spesialisering i indremedisin og infeksjonssykdommer, Haukeland universitetssykehus.

Forfatter har fylt ut ICMJE-skjemaet og oppgir ingen interessekonflikter.

\section{Pål Høvding (f. 1976)}

er overlege ved Ortopedisk avdeling, Haukeland universitetssykehus.

Forfatter har fylt ut ICMJE-skjemaet og oppgir ingen interessekonflikter.

\section{Paul Christoffer Lindemann (f. 1976)}

er lege i spesialisering ved Mikrobiologisk avdeling, Haukeland universitetssykehus. Forfatter har fylt ut ICMJE-skjemaet og oppgir ingen interessekonflikter.

\section{Haakon Sjursen (f. 1947)}

er spesialist i infeksjonsmedisin og indremedisin, overlege ved Infeksjonsseksjonen, Medisinsk avdeling. Haukeland universitetssykehus og professor ved Institutt for indremedisin, Medisinsk-odontologisk fakultet, Universitetet i Bergen.

Forfatter har fylt ut ICMJE-skjemaet og oppgir ingen interessekonflikter.

\section{Litteratur}

1. Reuben SS, Sklar J. Pain management in patients who undergo outpatient arthroscopic surgery of the knee. J Bone Joint Surg Am 2000: 82-A: $1754-66$

2. Koppensteiner W, Auersperg V, Halwachs-Baumann $G$. The use of inflammatory markers as a method for discharging patients post hip or knee arthroplasty. Clin Chem Lab Med 2011; 49: 1647-53.

3. Kirchhoff C, Braunstein V, Paul J et al. Septic arthritis as a severe complication of elective arthroscopy: clinical management strategies. Patient Saf Surg 2009: 3: 6 .

4. Kieser $\mathrm{C}$. A review of the complications of arthroscopic knee surgery. Arthroscopy 1992; 8: 79-83.

5. Piette A, Verschraegen G. Role of coagulase-negative staphylococci in human disease. Vet Microbiol 2009; 134: 45-54

6. Granslo H, Gammelsrud KW, Fredheim EA et al. Biofilm og antibiotikaresistens hos koagulase- negative stafylokokker. Tidsskr Nor Legeforen 2008; 128: 2746-9.

7. Freney J, Brun Y, Bes M et al. Staphylococcus lugdunensis sp. nov. and Staphylococcus schleifer sp. nov. Two Species from Human Clinical Specimens. IJSEM 1988; 38: 168-72.

8. Frank KL, Del Pozo JL, Patel R. From clinical microbiology to infection pathogenesis: how daring to be different works for Staphylococcus lugdunensis. Clin Microbiol Rev 2008; 21: 111-33.

9. Babu E, Oropello J. Staphylococcus lugdunensis: the coagulase-negative staphylococcus you don't want to ignore. Expert Rev Anti Infect Ther 2011: 9: 901-7.

10. Versalovic J. red. Manual of clinical microbiology. 10. utg. Washington, DC: ASM Press, 2011.

11. Grupper M, Potasman I, Rosner I et al. Septic arthritis due to Staphylococcus lugdunensis in a native joint. Rheumatol Int 2010; 30: 1231-3.

12. Kragsbjerg $P$, Bomfim-Loogna J, Törnqvist E et al. Development of antimicrobial resistance in Staphylococcus lugdunensis during treatment-report of a case of bacterial arthritis, vertebral osteomyelitis and infective endocarditis. Clin Microbiol Infect 2000; 6: 496-9.

13. Hellbacher C, Törnqvist E, Söderquist B. Staphylococcus lugdunensis: clinical spectrum, antibiotic susceptibility, and phenotypic and genotypic patterns of 39 isolates. Clin Microbiol Infect 2006; 12: $43-9$

Mottatt 23.1. 2012, første revisjon innsendt 29.3. 2012, godkjent 26.4. 2012. Medisinsk redaktør Are Brean. 